\title{
Pilot Study: Student Views about Lobola at a Peri-Urban University in South Africa
}

\author{
Kathryn Nel*, Saraswathie Govender, Katlego Hlokwe, Luvhengo M, Mogotsi KT, Mokalapa KT, Molopa LA, Monnye \\ KN, Monyepao SL and Rakomako BT
}

Department of Psychology, University of Limpopo, South Africa

*Corresponding author: Kathryn Nel, Department of Psychology, University of Limpopo, Private Bag X1106, Sovenga, South Africa, Email: Kathryn.Nel@ul.ac.za

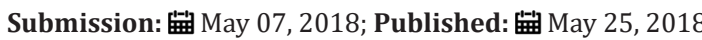

\begin{abstract}
Background: The process of Lobola or Bride price in South Africa is ongoing though there are detractors who state it commercialises females as a commodity. Africa.

Objective: The researched was aimed to glean the views of students towards Lobola at a previously disadvantaged tertiary institution in South

Method: The pilot study adopted a quantitative approach with a qualitative element. The research used a cross-sectional survey design with a Likert type scale and open-ended questions. A convenience sample was utilised with a 100 respondents (50 males and 50 females to ensure gender representivity)
\end{abstract}

Data Analysis: Descriptive statistics were used to analyse data as well as a Chi square test. Qualitative data from the open-ended questions was analysed using Thematic Content Analysis (TCA) and also presented in tabular format.

Results: The results indicated that the majority of the students support the practice of Lobola and see it as a necessary part of African tradition. There were no significant differences between males and females in the sample in their views towards the payment of Lobola.

Keywords: Africa; Bride-Price; Ethnic group; Tradition

\section{Introduction}

Lobola is defined as the money or gifts that are given to the bride's family by her husband and his family [1]. The process of Lobola is carried out by the elders from the family of the man and the woman in the presence of a messenger or negotiator (in Xhosa the Unozakuzaku) who is the person sent to discuss bride price with the family of the bride [2]. In the past century, Lobola was paid in the form of cattle, sheep and goats from the husband's family but today Lobola is often conducted in the form of monetary exchange. This is because of urbanisation and the fact that many families do not farm or have place for cattle. Lobola is believed to play a significant role in marriage and was traditionally designed to unite the two families together and to promote a feeling of trust and mutual understanding among them.

Because of the Lobola tradition, marriage is not just about the two people marrying but a contract between the two families as well. The marriage is therefore legitimized by the transfer of cattle from the groom's family, as well as ensuring certain rights, for instance, that the children of the marriage would legally belong to the father's lineage group [3]. According to Chabata [4], the meaning of Lobola has changed. Women whom Lobola is being paid for do not benefit or receive any share of the money. In the present days Lobola is being commercialized. Nowadays, most regard and perceive the process of Lobola as a business transaction, which only benefits the family of the woman. A monetary value is attached to the bride and most African families view their female child as a ticket to a better life.

Parker [3] argued that some of the changes and problems associated with the Lobola practice are related to cattle being replaced by money, arguing that families living in the city might not have the physical capacity to receive cattle. Therefore, as Parker argues, this change of using money rather than cattle results in the perception that paying for the bride now makes her the property of the groom, making her vulnerable to abuse by the husband and his family.

However, some argue that abandoning this custom will be another way of losing everything African. They believe that Lobola 
is socially beneficial because it brings the two families together and is an acknowledgement by the groom and his family of the precious gift; being the bride. There is the belief held by both men and women that the payment of Lobola creates a greater value and strength in marriage and that if Lobola is not paid, the marriage will not last [3]. From these arguments, it is clear that Lobola is a contentious issue that will be further explored in the following piece of writing (Table 1).

Table 1: Chi square for the research assumption.

\begin{tabular}{|c|c|c|c|c|c|}
\hline & Value & df & $\begin{array}{c}\text { Asymp. Sig. } \\
\text { (2-sided) }\end{array}$ & $\begin{array}{c}\text { Exact Sig. } \\
\text { (2-sided) }\end{array}$ & 0.19 \\
\hline Pearson Chi-Square & $3.31 \mathrm{a}$ & 2 & 0.19 & 0.19 & 0.16 \\
\hline Likelihood Ratio & 3.32 & 2 & 0.19 & 0.25 & 0.14 \\
\hline Fisher's Exact Test & 3.38 & 1 & 0.22 & 0.05 \\
\hline $\begin{array}{c}\text { Linear-by-Linear } \\
\text { Association }\end{array}$ & $1.49 \mathrm{~b}$ & 100 & & & \\
\hline N of Valid Cases & & & & \\
\hline
\end{tabular}

South Africa is a diverse country with many different ethnic groups. The practice of Lobola exists, and is slightly different within each ethnic group. Amongst the Lobola in Pedi is Magadi and in sotho it is Mahadi, Zulu ilobolo, and in Shona it is roora [5]. In the Basotho culture, the process of Lobola is carried out by the representatives (Bomaditsela) of the two families whom amongst them are the uncles from the groom and bride's mother's side and the father's side. The couple are regarded married immediately after the price has been agreed on and the first instalment been made [6].

In the Bapedi culture, the man will alert his parents and his parents would appoint someone, normally the uncles to be the negotiators and to head the process. The uncles would go the woman's house and alert the woman's family. The family would then give the uncles of the groom a day for their return where they will hold proper negotiations where the negotiations takes place until both families are satisfied with the price to be paid [7].

In the Tshivenda culture marriage is not just an intimate relationship between two people, however, it is the connection of two families therefore the practice of arranged marriage [8]. When a man wants to marry, he first alerts the parents so that a background investigation of the girl be conducted. If the parents are satisfied with the girl, they will then send an intermediary to the girl's family and propose to the girl on the behalf of their son [8]. Amongst the Vatsonga people, a man is not allowed to choose a wife for himself, instead when he is ready to take a wife and has enough money to pay for Lobola he has to inform his elders and they will go and look for a wife for him and find a wife who has recently been initiated [9]. This research was a pilot study with the proposition: African female undergraduate students registered at the University will hold more negative views towards Lobola than males.

\section{Method}

\section{Population and Setting}

The population of the study consisted of 50 female and 50 male African (totalling 100) students at a semi-urban, previously disadvantage university catering to a majority, black African demographic in South Africa.

\section{Research Design}

The research was in the form of a pilot study using a crosssectional survey design with a Likert type scale and open-ended questions which formed the qualitative element of the investigation.

\section{Instrument}

For the purpose of this pilot study, a questionnaire was designed in two different sections; open-ended and close-ended questions, which were included in the questionnaire based on research by Khomari et al. (2012).

\section{Procedure and Sampling}

Data was collected through the use of questionnaires. A convenience sample of students was utilised. They were approached after classes and asked to fill the survey in. The questionnaires were distributed to 100 students ( 50 males and 50 females to ensure gender representivity). The researchers collected the questionnaires immediately after they were filled in.

\section{Data Analysis}

Table 2: Themes emerging from the open ended questions

\begin{tabular}{|c|c|}
\hline Emergent Themes and Responses & Brief Description \\
\hline $\begin{array}{l}\text { Theme 1: Necessity } \\
\text { I believe it is an important part of our } \\
\text { culture. } \\
\text { We must keep our culture strong. } \\
\text { It is something we believe is } \\
\text { necessary. }\end{array}$ & $\begin{array}{l}\text { Students have a clear } \\
\text { understanding of the necessity } \\
\text { of Lobola and the need to } \\
\text { uphold traditional aspects of } \\
\text { their culture. }\end{array}$ \\
\hline $\begin{array}{l}\text { Theme 2: Media influence } \\
\text { No it does not influence how I think. } \\
\text { I think it is Whites who say these } \\
\text { [negative] things. } \\
\text { Aaah they always [media] say } \\
\text { something it is better to ignore them. }\end{array}$ & $\begin{array}{l}\text { students maintain that media } \\
\text { does not have an influence of } \\
\text { how they perceive Bride price } \\
\text { or Lobola }\end{array}$ \\
\hline
\end{tabular}


Theme 3: Lobola and its meaning No it is about money now.

I think that we do not really think about those true meanings.

Well, I think that we don't know any more what it means...not so much anyway.

Quantitative data was analysed using descriptive statistics (frequencies, tables and a chi square analysis to see if there were any significant differences between males and females). Descriptive statistics were used to summarise data obtained. Qualitative data from the open-ended questions was analysed using thematic analysis by familiarisation and immersion with the data, coding, inducing themes and reporting them(Table 2).

\section{Results and Discussion}

The overall sample consisted of 100 respondents between the ages of 16-34 (Standard Deviation (SD) $=2.40$ ) within the different African ethnic groups in South Africa with the Pedi people being the most dominant. Fifty percent (50\%) were female and 50\% were male. Ninety-eight percent $(98 \%)$ of the respondents reported to being single and $2 \%$ were married. The sample consisted of Pedi (63\%), Venda (11\%), Swati (8\%), Ndebele (2\%), Zulu (3\%), Sotho (2\%), Tswana (1\%) and the other ethnic groups (Shona and Tsonga) made up $5 \%$ of the sample each.

In terms of patriarchal practices and influences when paying Lobola, $64 \%$ of the male respondents stated that it was appropriate to pay Lobola when they were ready to marry. However, $26 \%$ of the males said they would not pay Lobola while $6 \%$ answered that maybe they would. Four percent (4\%) did not answer the question. This was supported by female respondents as $80 \%$ of them stated that they did want Lobola to be paid for them while $12 \%$ stated that they did not want Lobola to be paid and $8 \%$ do not know if they wanted it paid for them. Seventeen females (34\%) and 17 males (34\%) stated that Lobola influences co-habitation, while $11(22 \%)$ females and 18 (36\%) males did not think this was the case. Twenty-one (42\%) of the female respondents and $14(28 \%)$ of the males responded maybe. Some responses were not received to this question. The majority of the students responded to not being influenced by negative media reporting about Lobola 29 (58\%) of the male sample and $25(50 \%)$ of the female sample. Overall the research proposition namely: Female undergraduate students registered at the University will hold more negative views towards Lobola than males (level of significance $=p \leq 0.05$ ) was not upheld.

The findings from the chi-square test indicated that there was no significant relationship between the respondents' sex and any negative attitudes towards Lobola $(p=0.18)$. As there was a difference in one of the cells which had a count of less than 5 the Fishers' Exact Test was used.

\section{Results from qualitative data}

Themes that emerged indicated that students had knowledge and understood the necessity of Lobola for bringing families together. They also did not believe that any negative media reports likening Lobola to a commercial transaction. Conversely, they did believe that its original meaning was lost which tends to be in conflict to the theme of necessity. More research needs undertaking to clarify this aspect of the research.

\section{Conclusion}

The results of the study indicate that most of the students still believe in the practice of Lobola because they feel it is their tradition and they need to uphold those traditional values. This is supported by the fact that the majority of the males stated that they would still pay Lobola and most females in the research indicated that they would like to have Lobola paid for them. There were no significant differences between males and females on responses to any of the survey questions. The research proposition that females were more likely to hold negative views towards Lobola than males was not upheld as there was no significant relationship between the respondents' sex (male or female) and any negative attitudes towards Lobola. The research was a pilot study and a more in-depth investigation using random sampling and inferential statistics needs undertaking with a more in-depth qualitative element using focus groups or interviews.

\section{References}

1. Khomari D, Tebele C, Nel K (2012) The social value of lobola: perceptions of South African college students. JPA 22(1): 143-145.

2. Chireshe E (2010) Lobola: The perception of Great Zimbabwe University students. The Journal of Pan African studies 3(9): 211-221.

3. Parker G (2015) The practice of Lobola in contemporary South African society. Journal of third world studies 32(2): 175-190.

4. Chabata T (2011) The commercialization of Lobola in contemporary Zimbabwe: A double edged sword for women in Buwa. A journal of African Woman's Experiences p. 11-14.

5. Ansell N (2001) 'Because it's our culture! (Re)negotiating the meaning of Lobolain Southern African secondary schools' Journal of Southern African Studies 27(4): 697-716.

6. Semenya DK (2014) The practical guidelines on the impact of mahadi [bride price] on the young Basotho couples prior to marriage. Theological Studies 70(3): 6-9.

7. Mankga RW (2013) Language usage is some traditional rituals in Northern Sotho Unpublished Master's thesis. University of Limpopo, Sovenga, South Africa.

8. Raphalani TD, Musehane MN (2013) Arranged marriage practices of the Vhavenda community of the Vhembe district, Limpopo province, South Africa. Journal of Language and Culture 4(2): 18-22.

9. Khosa MA (2009) Symbolism in Xitsonga cultural ritual ceremonies. 
(c) (i) Creative Commons Attribution 4.0 International License

For possible submissions Click Here

Submit Article

\begin{tabular}{|c|c|c|}
\hline PPRS & $\begin{array}{l}\text { Psychologogy and } \\
\text { Psychootherapy. } \\
\text { Research Study }\end{array}$ & $\begin{array}{l}\text { Psychol Psychother Res Stud } \\
\text { Benefits of Publishing with us } \\
\text { - High-level peer review and editorial services } \\
\text { - Freely accessible online immediately upon publication } \\
\text { - Authors retain the copyright to their work } \\
\text { - Licensing it under a Creative Commons license } \\
\text { - Visibility through different online platforms }\end{array}$ \\
\hline
\end{tabular}

